\title{
THE INTERNAL IRON KINETICS IN MICE
}

\author{
J. VÁCHA, V. ZNOJIL, J. HOLÁ, J. DUNGEL \\ Institute of Biophysics, Czechoslovak Academy of Sciences, 61265 Brno
}

Received May 24, 1982

\begin{abstract}
Vácha J., V. Znojil, J. Holá, J. Dungel: The Internal Iron Kinetics in Mice. Acta vet. Brno, 51, 1982: 3-22.

Using mice of the strain $\mathrm{C} 57 \mathrm{BL} / 10 \mathrm{ScSnPh}$ a three-week study was made of radioactivity in the plasma, erythrocytes, liver and haeme and non-haeme iron of the bone marrow and spleen, and of the urine and faeces following ${ }^{59} \mathrm{Fe}$ administration. On the basis of the experimental data obtained a mathematical model was used to determine the rates of flows between the assumed iron compartments of the organism. By means of the chemical determination of the haeme and non-haeme iron of these organs it was possible to express these flows in absolute values, thus forming an overall model picture of the ferrokinetics of mice.

It is clear from the model that the central ferrokinetic pool in mice consists not only of the plasma but also of a further space of considerable size and rate of exchange, identifiable with considerable certainty with the extravascular and lymphatic spaces. Non-haeme pools of considerable sizes were also found in the erythropoietic organs. The one with the faster rate of exchange has a mostly pre-haeme character; the second, of approximately ten times the size, characterized by a slower rate of exchange, does not have any immediate relation as a whole to erythropoiesis and is thus the main cause of discrepancies between the results of ${ }^{59} \mathrm{Fe}$ incorporation into the erythropoietic organs and the actual intensity of erythropoiesis.
\end{abstract}

Ferrokinetics, iron compartments, haeme and non-haeme iron, bone marrow, spleen, ${ }^{59} \mathrm{Fe}$-incorporation method.

Knowledge on the internal exchange of iron in mice is as yet extremely incomplete. A better understanding of it would, however, be useful, particularly in view of the widespread use of ${ }^{59} \mathrm{Fe}$ in haematological studies in this animal. Works so far published provide only values for the overall plasma turnover in mice (Brodsky et al. 1966), or the distribution of ${ }^{59} \mathrm{Fe}$ in the main organs of mice after a short time interval following tracer administration (Smith and Clayton 1970). We made a long-term study of ${ }^{59} \mathrm{Fe}$ shifts in the mouse organism, concentrating on the erythropoietic organs. A reasonably adequate picture of the direction and magnitude of shifts of iron between compartments was obtained using a mathematical model. A decomposition of the incorporation of ${ }^{59} \mathrm{Fe}$ into the erythropoietic organs into flows to individual compartments inside these organs has important consequences for the use of the labelled iron incorporation method as an indicator of erythropoiesis.

\section{Materials and Methods}

1. The Animals. All experiments were performed on males of the strain $\mathrm{C} 57 \mathrm{BL} / 10 \mathrm{ScSnPh}$ bred in our institute, $11.5-14$ weeks old, mean body mass $28.8 \mathrm{~g}$. The mice were kept at a temperature of $22{ }^{\circ} \mathrm{C}$, diet Larsen (Velaz, CSSR), with"an iron content of $6.3-7.5 \mathrm{mmol} / \mathrm{kg}$, water ad libitum.

2. ${ }^{59} \mathrm{Fe}$ Administration. The form of administration used was ferrous citrate labelled with ${ }^{50} \mathrm{Fe}$, $\mathrm{mfr}$. Rotop (GDR), supplied in an isotonic buffer containing ascorbic and citric acids, supplemented with $0.9 \%$ benzylalcohol, $\mathrm{pH} 4-6$, specific activity $10.5-34.3 \mathrm{GBq} / \mathrm{mmol} \mathrm{Fe}$. The pre- 
paration was diluted immediately prior to administration with saline to an equivalent of 1.8 or 5.4 nmol elementary iron per mouse, corresponding to a radioactivity of $5.6-18.5{ }^{104} \mathrm{~Bq}$ per mouse. The diluted solution was administered in quantities of $0.1 \mathrm{ml}$ into the tail veins, the point of injection being compressed immediately and subsequently being sprayed with plastic skin (Acutol, mfr. Spofa). Control measurements of the radioactivity of the tail in the region of injection on 20 mice showed that penetration of the preparation from the point of injection into the circulation using this method was practically complete (a maximum of $2 \%$ applied radioactivity remained locally).

The tracing of the curve of ${ }^{59} \mathrm{Fe}$ clearance for a period of several weeks is technically very difficult with an animal which has a blood volume as small as that of the mouse, since during this period the radioactivity of plasma samples falls by more than three orders. To ensure that plasma samples contain a sufficient quantity of radioactivity after two or three weeks it was necessary to administer ${ }^{59} \mathrm{Fe}$ citrate directly intra venam. Given that $0.1 \mathrm{ml}$ solution was administered, containing less than $50 \%$ of the original ${ }^{59} \mathrm{Fe}$ citrate solution, and that the plasma volume of the mouse strain used is $1.4 \mathrm{ml}$ (Vácha 1975), the original preparation was diluted in vivo in the plasma in a ratio of more than 1:30, the amount of elementary $\mathrm{Fe}$ adminstered representing a maximum of about $10 \%$ of that in the plasma of the animal. Under such circumstances the administration of ${ }^{59} \mathrm{Fe}$ citrate may be considered a method practically as effective as the use of ${ }^{59} \mathrm{Fe}$ bound to transferrin (Bothwell et al. 1957, Monti et al. 1963). The actual course of the clearance curve thus obtained is not steeper than that of the curve we obtained in the first $30 \mathrm{~min}$ after ${ }^{59} \mathrm{Fe}$ administration bound to transferrin in other experiments (Vácha 1975). If the ${ }^{59} \mathrm{Fe}$ were imperfectly bound to the plasma transferrin one would have to expect a shortening of the half-time of clearance (Morgan 1974). In addition the course of radioactivity in the liver (Fig. 6) shows that the activity rapidly appearing in the liver is very minute, corresponding roughly to the amount of blood retained. Nor does the plasma curve (Fig. 1) show any extremely rapid component of decline, at least not one of discernible magnitude. It follows from this that any proportion of iron not bound to transferrin is entirely negligible in our experimental regimen, since according to published data it should above all be apparent in a very rapid initial decline in the plasma and the fast depositing of this iron in the liver, which was not the case. The proportion of unbound iron can be estimated at less than $1 \%$ of administered activity.

3. ${ }^{69} \mathrm{Fe}$ Clearance from Plasma. At selected intervals following ${ }^{59} \mathrm{Fe}$ administration groups of 10-35 mice with ${ }^{59} \mathrm{Fe}$ administered were investigated along with $3-5$ control animals to which ${ }^{59} \mathrm{Fe}$ had not been administered (in order to establish the background radioactivity of the tissues.) The animals were sacrificed at $0900 \mathrm{~h}$ in all cases by bleeding from the axillar blood vessels under ether narcosis. The blood was transferred using a heparinized pipette to a test-tube containing powdered heparin and after 20 min centrifugation at $1400 \mathrm{~g} 0.25 \mathrm{ml}$ plasma was taken from each sample, 0.75 distilled water added, and this mixture was thoroughly shaken and the extinction of oxyhaemoglobin from any haemolysed erythrocytes present was spectrophotometrically measured at a wavelenght of $540 \mathrm{~nm}$. Using a calibration curve the proportion of haemolysed erythrocytes in each plasma sample was then calculated. Following the measurement of extinction $2 \mathrm{ml}$ trichloroacetic acid ( $c=1.22 \mathrm{~mol} / \mathrm{l}$ ) was added to each sample, the sample was stirred, centrifuged, and the radioactivity of the supernatant measured. On precipitation of the haemoglobin released by haemolysis using trichloroacetic acid a certain unprecipitable fraction remains, according to our previous results (Holá et al. 1975), the amount of this depending on the time elapsed from ${ }^{59} \mathrm{Fe}$ administration. This dependence was utilized in the correction of the influence of haemolysis on plasma radioactivity according to the formula:

$$
\text { corrected radioactivity of } 0.25 \mathrm{ml} \text { plasma }=\frac{0.25}{0.25-e}\left(P-\frac{e \cdot E \cdot t}{100}\right),
$$

where $e$ is the amount (in $\mathrm{ml}$ ) of haemolysed erythrocytes in a $0.25 \mathrm{ml}$ sample of plasma, $P$ is the total radioactivity measured in $0.25 \mathrm{ml}$ plasma withdrawn (contaminated by haemolysed erythrocytes), $E$ is the radioactivity of $1 \mathrm{ml}$ of erythrocytes in the given animal and $t$ is the time-dependent portion of radioactivity from the haemolysed erythrocytes which is not precipitable by trichloroacetic acid (in \%).

Intact animals were treated in the same way as those to which ${ }^{59} \mathrm{Fe}$ had been administered. The radioactivity of these control plasma samples was randomly distributed around a very low value (6 impulses $/ \mathrm{min}$ ), which was subtracted from the experimental sample. The experimental samples were then corrected for the mean mass of animals. Of the corrections made the one with the most pronounced effect (up to $35 \%$ of the original value after the longer intervals following ${ }^{59} \mathrm{Fe}$ application) was that of the correction for the content of haemolysed erythrocytes, the corrections for the natural radioactivity of plasma and the body mass of animals being almost negligible.

The radioactivity of the plasma samples withdrawn was finally calculated in respect of the total 
plasma volume determined in turn from the degree of dilution of ${ }^{59} \mathrm{Fe}$ at the time $\mathrm{t}_{0}$ (at the moment of ${ }^{59} \mathrm{Fe}$ application). The conversion factor for $0.25 \mathrm{ml}$ plasma was 7.73 .

4. The Appearance of ${ }^{59} \mathrm{Fe}$ in Circulating Erythrocytes. The erythrocytes sedimented on centrifugation of blood samples were washed three times in an excess of saline, and following the final centrifugation ( $20 \mathrm{~min}$ at $1400 \mathrm{~g}$ ) were measured out in amounts of $0.1 \mathrm{ml}$, haemolysed with distilled water, and their radioactivity measured. The values obtained were corrected for washing solution retained (by a factor of 0.965 ), for the natural radioactivity of the erythrocytes, and for body mass of animals. The radioactivity of the number of erythrocytes 'withdrawn was calculated in respect of the total volume of circulating erythrocytes, determined using erythrocytes labelled with ${ }^{59} \mathrm{Fe}$ in a parallel experiment (Vácha 1975). The conversion factor for samples of $0.1 \mathrm{ml}$ was 7.78 or 7.68 according to the body mass of animals.

5. Organ Measurements. Following the bleeding of the animal the spleen was removed and weighed and its radioactivity measured. The liver was perfused in situ with saline injected into the v. portae and the v. cava cran. The complete skeleton, free of all soft tissue, was obtained by placing the carcasses of the animals in a colony of the beetles Dermestes vulpinus Fbr. (kept according to Grulich 1977); prior to measuring it was divided into individual bones or groups of bones. All organ samples were corrected for natural tissue radioactivity.

6. ${ }^{59} \mathrm{Fe}$ Incorporation into the Haeme and non-Haeme Fractions of Iron in Organs. In another group of animals, in addition to the overall radioactivity of the spleen and skeleton, the radioactivity of the haeme fraction in these organs was also measured at selected intervals after ${ }^{59} \mathrm{Fe}$ administration. The organs were mechanically homogenized after freezing with liquid nitrogen, the cells haemolyzed with distilled water, and the haeme fraction extracted using acid ethylacetate (for details see Vácha et al. 1978).

7. ${ }^{59} \mathrm{Fe}$ Excretion in Faeces and Urine. A group of $18{ }^{59} \mathrm{Fe}$ administered mice were placed singly in glass funnels with a floor of coarse wire netting, allowing faeces and urine to be collected. The material collected every $24 \mathrm{~h}$ was homogenized and its radioactivity measured.

8. Measurement of ${ }^{5} \mathrm{Fe}$ Activity. This was measured using an Automatic Gamma Well Counting System (Nuclear Chicago) in the range 0.5-14. MeV, efficiency $19 \%$. All samples were formed into approximately similar geometrical shapes and measured together with a standard formed by a known fraction of administered radioactivity. The lenght of measuring was chosen for the given background so as to give a dispersion of less than $5 \%$ of the measured value even in the least radioactive samples.

9. Determination of Total and Haeme Iron in Organs. The total content of elementary iron in the bones, liver, spleen and whole body of 10 intact mice was determined. The organs were removed as described following bleeding of the animal, the liver being perfused with saline in vivo. Prior to the determination of the content of iron in the whole body the digestive tract was cleaned of its contents. The tissues were mineralized with perchloric acid and hydrogen peroxide and then stained with phenanthroline. In another group of mice the same organs were subjected to the extraction of haeme iron as described. Details of the method used are given in Vácha et al. 1978. The concentration of plasma iron was determined using a Böhringer (Mannheim) kit.

10. Mathematical Analysis of a system with as many degrees of freedom as the one studied is difficult to perform by means of the direct approximation of curves by the least squares method. One solution which is more readily applicable is mathematical modelling, which was used here.

In the first phase of the calculations the changes in the radioactivity of individual organs in time were approximated by means of curves according to a computer programme which heuristically seeks the optimum number and parameters of exponential components (Kindler 1970). (Since the results of these calculations were merely the starting-point of modelling, they will not be given here except for the decomposition of the plasma clearance curve.) The actual modelling was performed as follows: on the basis of the number of exponential components of the organ curves the minimum number of ferrokinetic compartments in the organs studied and in the whole organism was estimated. On the basis of established facts concerning ferrokinetics a preliminary scheme of the flow of iron between compartments was drawn up. The parameters of the exponential components of the organ curves served as a guideline in this, since it was possible e. g., to assume the existence of a flow between compartments with similar slopes of exponentials. Some organs or tissues contained a single compartment (plasma, erythrocytes), others several compartments (bone marrow, spleen).

Let us designate the size of a compartment (of labelled and non-labelled iron), according to Skinner et al. (1959), as $Q_{i}$ and the amount of ${ }^{59} \mathrm{Fe}$ present in it at a given moment as $\mathrm{q}_{i}$. We assume that the compartment is internally homogenous, and that there is no delay on mixing of the material. Let $\mathrm{k}_{i j}$ be the total amount of (labelled and unlabelled) iron flowing to compartment $i$ from compartment $j$ per unit time. The rate constant of flow is then defined as $\lambda_{i j}=\mathrm{k}_{i j} / \mathrm{Q}_{j} ; \lambda_{i j}{ }^{-1}$. $\ln 2$ is the half-time (T 1/2) of flow.

A FORTRAN programme was built for the digital computer ZPA 600, allowing the calculation, 


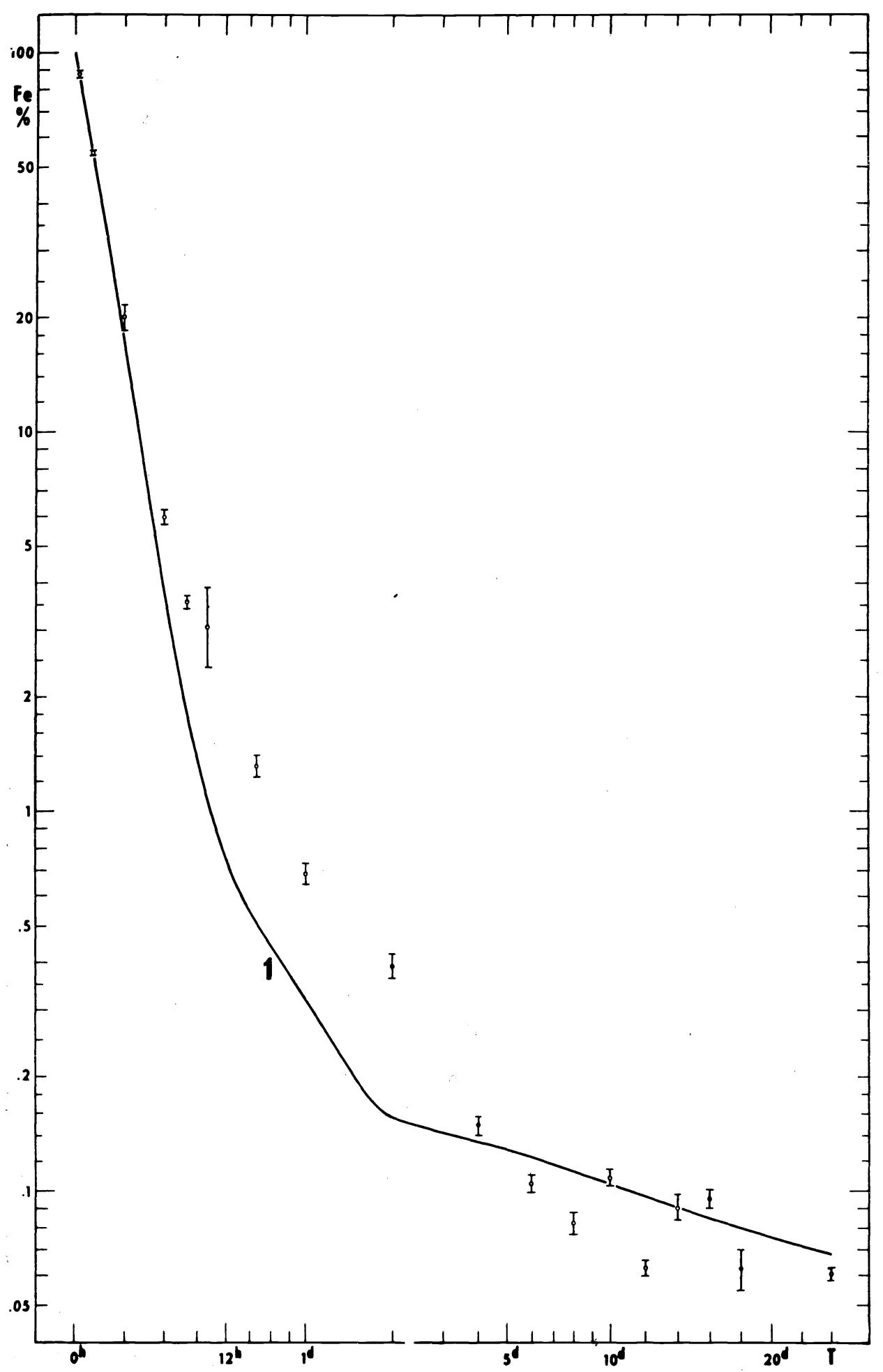


on the basis of the number of compartments and the rate constants $\lambda_{i j}$ entered, of the course of radioactivity of individual compartments in time, i.e. the calculation of the function $q_{i}(t)$. The calculation was performed by integration of the flow between compartments using the trapezoidal rule. By adding together the curves $q_{i}(t)$ of all compartments contained in a given organ it was possible to obtain the sum theoretical curve of its radioactivity directly comparable with the experimental data. The above-mentioned preliminary decomposition of the time series of experimental values also offered the starting-point for an initial estimate of some rate constants $\lambda_{i j}$. The exponent of the first (steepest) exponential component of the clearance curve of plasma corresponds to the rate of the sum primary flow from plasma to all other compartments. It therefore represents a value which must be approximately equal to the sum of the rate constants of these shifts $\left(\Sigma \lambda_{i_{1}}\right)$. A knowledge of the other parameters of the exponential components of the fall in radioactivity of plasma makes it on the other hand possible to estimate the sum outflow of ${ }^{59} \mathrm{Fe}$ from the organs. In the model calculation the rate constants were varied in physiologically reasonable limits so as to obtain the maximum agreement of theoretical sum organ curves with the experimental data. The rate constants corresponding to this maximum agreement were taken as the basis of our model of the ferrokinetics of mice, as is shown in Figs. 9 and 10. Details of the modelling of individual compartments and a discussion of the question of the reality of the results can be found in the section Results and Discussion.

To allow the size of compartments and flows between them to be expressed in relation to the overall content of iron in the organism, the model calculation was performed up to the 140th day after tracer administration, when the distribution of ${ }^{50} \mathrm{Fe}$ in the organism has already reached a virtually steady state (in this calculation the mean life span of erythrocytes is equal to $42.1 \pm 0.6$ days according to our results using the incorporation of ${ }^{14} \mathrm{C}$-glycine in the same mouse strain, Horký et al. 1978). In this way the values $Q$ of the total content of iron were obtained for each compartment of the model and expressed as percentages of the total iron content of the organism. Then the values $Q$ and $\lambda$ were used to calculate the magnitude of intercompartmental flows $k_{i j}$, and again expressed in relation to the overall $\mathrm{Fe}$ content of the organism.

\section{Results and Discussion}

1. ${ }^{59} \mathrm{Fe}$ Clearance from Plasma (Fig. 1). As is apparent from the experimental data, the curve of ${ }^{59} \mathrm{Fe}$ clearance from the plasma falls roughly into three stages. The initial exponential decline begins to level out between the 3rd and 4th hours following ${ }^{59} \mathrm{Fe}$ administration, and passes into another approximately exponential stage. The second clear turning point in the curve lies around the 2nd day, followed by the last, again approximately exponential section of the curve. Approximation of the experimental data, by decomposing them into exponential components, led to the relation:

$$
P(t)=81.3 e^{-15.9 t}+16.7 e^{-5.14 t}+1.49 e^{-0.876 t}+0.112 e^{-0.0243} .
$$

The first two components are contained in the first section of the curve, the third and fourth correspond to the second and third sections described above, respectively.

The plasma iron compartment may from the point of view of the modelling of the ferrokinetics be considered internally homogenous (Cavill and Ricketts 1974, 1980) and deviations from a simple exponential course may be regarded as due to tracer reflux into the plasma. The first exponential component of the clearance curve then represents the actual flow of ${ }^{59} \mathrm{Fe}$ out of the plasma and in our experiment leads to the half time of ${ }^{59} \mathrm{Fe}$ clearance of $\mathrm{T} 1 / 2=1.046 \mathrm{~h}$. In our

Fig 1

The radioactivity of the whole plasma following i.v. administration of ${ }^{59} \mathrm{Fe}$ to mice, plotted against time. Abscissa: time (h-hours, d-days), ordinate: \% administered radioactivity. Circles with bars indicate experimentally ascertained mean values \pm S.E. The curve is the result of the model calculations. 
model scheme (Fig. 9) the plasma compartment occupies a central position. Flows of iron are assumed from the plasma into almost all other compartments. The rate constants of the flows must fulfil the condition that their sum corresponds to the exponent of the first exponential component of the function (1).

Estimation of the course of radioactivity of the other iron compartments under modelling made possible a concrete interpretation of the ${ }^{59} \mathrm{Fe}$ clearance curve, as will be shown in detail in connection with individual compartments. A brief preliminary description of the influence of individual refluxes may be made as follows: the flattening out of the clearance curve slope between the 3rd and 4th hour after tracer administration is caused in our model mainly by the return of



Fig. 2

Radioactivity of the whole skeleton after i.v. administration of ${ }^{59} \mathrm{Fe}$ to mice, plotted against time. Empty circles indicate experimentally obtained mean values of the total radioactivity of the skeleton, full circles experimentally ascertained mean values of radioactivity of the haeme fraction of the whole skeleton. Curves $1,2,3,4$ and 8 correspond to the calculated radioactivities of the compartments with those numbers, the thicker, unmarked curve being the result of their summation, representing an approximation of the total radioactivity in the skeleton. Other notes as Fig. 1. 
iron from the extravascular pool, whether that of the erythropoietic organs (part of compartments 2 and 5) or of other organs not studied by us (compartment 10). The second flattening in the slope of the clearance curve around the second day is, on the other hand, connected both with the return of iron from the fixed storage pool localized in the liver (compartment 9), in organs not studied (compartment 11) and from erythrocytes (compartment 8). As will be demonstrated it does not seem that possible ineffective erythropoiesis in the given mouse strain had any substantial effect on the results.

It must, however, be emphasized that the scheme of refluxes proposed is the result of a very complex systemic interaction between individual flows of iron and the individual refluxes set out here must be understood as the final result, affected by many other flows between neighbouring compartments. Particularly in view of the existence of a large pool of rapidly exchanging iron in the organs not studied (compartment 10) no simple attribution can be made of components of function (1) to individual refluxes to the plasma, and it would be better to keep to the modelling of the ferrokinetic system as a whole on the computer.

2. The Erythropoietic Organs. Bone marrow activity measured (Fig. 2, empty circles) reaches its maximum between the 4th and 6th hours after tracer administration (around $31 \%$ applied radioactivity), then falls steeply up to about the 3rd day, when the slope of the curve flattens out. The thick curve is the sum theoretical curve of the marrow, and the curves at the bottom of the figure, $1-4$ and 8, represent its components (numbers corresponding to the compartments in Fig. 9). Curves 1 and 8 were derived from an estimate of the residual amount of blood in the bone marrow. Leaving these aside, it seemed reasonable to decompose the sum curve into three large components, 2, 3 and 4, and to consider the bone marrow the sum of three ferrokinetic compartments accordingly. The maxima of these curves correspond to values of $15.7,15.2$ and $3.5 \%$ administered radioactivity respectively.

On the basis of our experiments and of knowledge to date one may attempt a physiological interpretation of compartments $2-4$. Compartment 3 in the model was identified with the haeme iron in the marrow and the rate of inflow and outflow was selected so as to correspond both to the appearance of labelled erythrocytes in the peripheral blood (Fig. 5) and the course of the clearance of labelled iron from the plasma and the behaviour of compartment 10. This assumption was tested in an additional experiment where the incorporation of ${ }^{59} \mathrm{Fe}$ into the haeme of the bone marrow was investigated (full circles in Fig. 2). The agreement between the experimental data and component 3 is almost total, and indicates that this component does indeed correspond to the build-up of iron in the haeme compartment of the marrow and its flushing out into the peripheral blood.

No physiologically unequivocal explanation of component 2 can be reliably proposed as yet. It follows from our experimental results that the flow of iron between the plasma (compartment 1) and the haeme iron in erythroblasts (compartments 3 and 6) must in part go through some intermediate compartment where a delay occurs, since the rising section of the curve of ${ }^{59} \mathrm{Fe}$ incorporation into the haeme fraction of the two erythropoietic organs does not immediately reflect the supply made available by the plasma as shown by the clearance curve, but shows a considerable time-lag. On the other hand an explanation must be offered for the origin of those refluxes to the plasma for which the behaviour does not match that of compartments outside the erythropoietic organs. For both these reasons component 2 may be considered a complex compartment, contai- 
ning both iron destined for incorporation into haeme, deposited in erythroblasts (the pre-haeme pool) and iron destined to return to the plasma, partly identifiable with the extravascular space of the marrow. In a state of equilibrium the size of compartment 2 or 5 is very small, smaller than that of compartments 3 or 4 or 6 or 7, and also considerably smaller than the iron content in the erythrocytes of peripheral blood contained in the organs; this is shown both by the model and the experimentally ascertained ${ }^{59} \mathrm{Fe}$ distribution 90 days after administration. Our results thus show that, at least in mice, a pre-haeme pool (Pollycove 1966) does exist in the bone marrow and the spleen, but it is much smaller than above author assumed for man. This is in accord with the view of Finch et al. (1970), who deny the existence of large pre-haeme pools in the erythropoietic organs and (in accord with our model) deduce that much of the reflux is from the extravascular space and the lymph vessels (compartment 10 in our model). As we shall

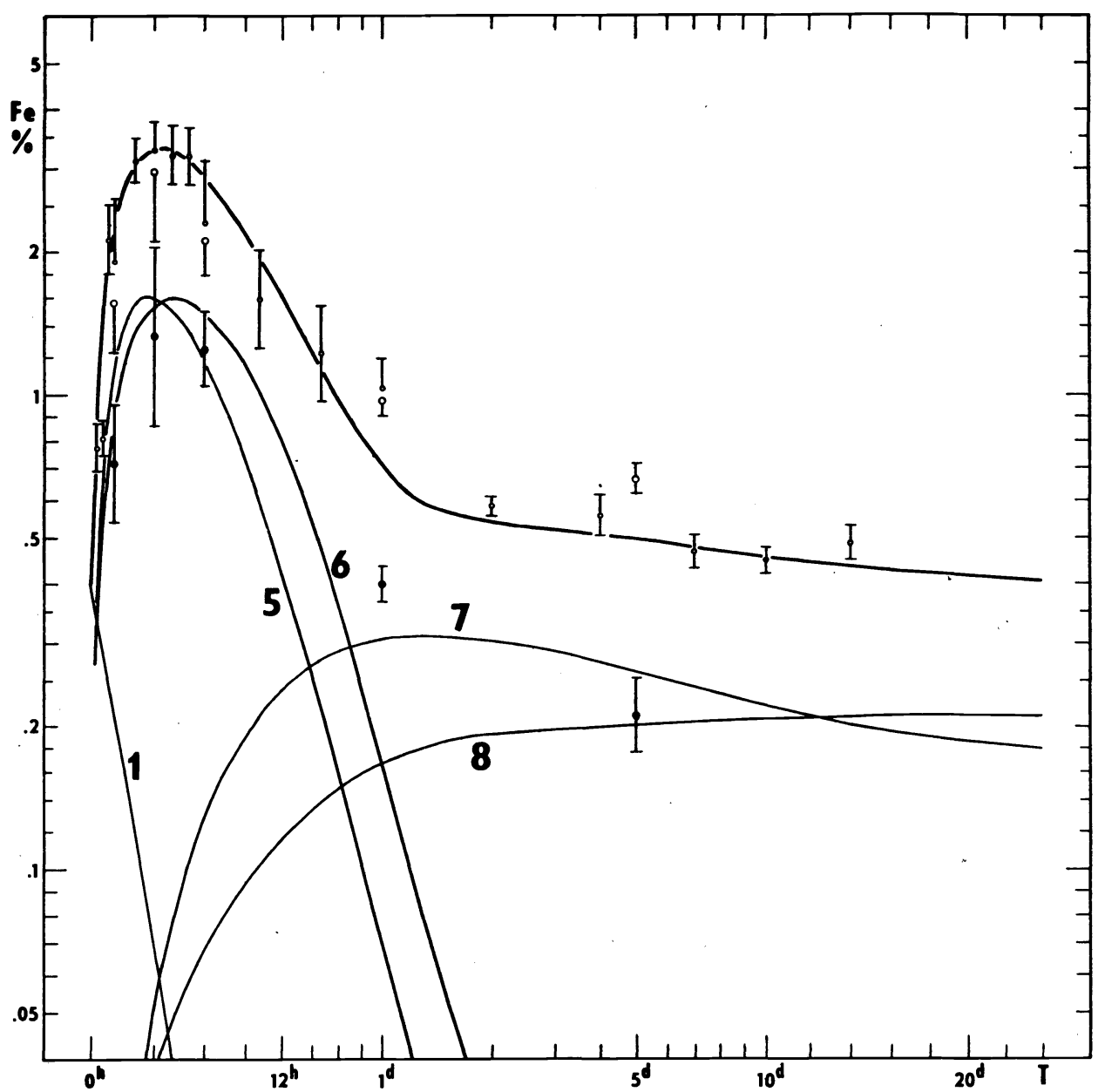

Fig. 3

Radioactivity of the spleen following i.v. administration of ${ }^{59} \mathrm{Fe}$ to mice, plotted against time. Notes as in Fig. 2. 
demonstrate below, the curve of the radioactivity of the organs not studied directly (compartments 10 and 11) has two quite distinct components (Fig. 7). The more rapid of these can be identified with the lymphatic reflux of iron into the plasma. In spite of a certain similarity between component 2 and the last component mentioned, it is probable, in view of their properties, that other mechanisms must participate in the creation of component 2, returning iron to the plasma in the period from approximately $3 \mathrm{~h}$ to one day after tracer administration. This requirement is well satisfied by the mobile iron fraction in erythroblasts. On the other hand, however, the localization of part of component 2 or 5 outside the erythroblasts (mainly in the extravascular space) is also indicated by the smaller decline in ${ }^{59} \mathrm{Fe}$ incorporation into the non-haeme fraction compared with the haeme fraction following irradiation with a dose of $2.87 \mathrm{~Gy}$ (Vácha 1982, p. 22). If component 2 were entirely localized in the erythroblasts a postirradiational depopulation of roughly $99 \%$ would certainly bring about a much more pronounced fall of this component.

The fact that the marrow component 3 (in both the experiments and the model) corresponds to the curve of the appearance of erythrocytes in the peripheral blood (Fig. 5) indicates that ineffective erythropoiesis in mice of the given strain is not particularly significant, making up about $5 \%$ of total erythropoiesis (taking into consideration the methodical error of haeme iron extraction).

Component 4 of the bone marrow contains, according to the results of the extraction experiment, non-haeme iron, similarly as component 2 . This would seem to be some form of storage iron, perhaps catabolic ferritin contained in the RES of the bone marrow, probably also the less mobile fraction of iron deposited in erythroblasts. In the time range studied in our experiments this component plays a relatively minor role. The model assumes only the exchange of iron between it and the marrow component 3, and reflux into the plasma; these flows are readily imaginable from the physiological point of view. The flow from compartment 4 to compartment 3 would partly correspond to the transfer of RES ferritin to the erythroblasts for the formation of haemoglobin, which may, according to Jacobs (1974), actually occur to a small extent. The existence of compartment 4 is clear in view of the course of the sum curve of the bone marrow. The rate constants of flow from compartment 4 , however, may be subject to considerable methodical error in view of the imprecise determination of the amount of residual erythrocytes in the bone marrow (compartment 8 ). In view of this error the flows from this compartment were reduced to the flow into compartments 3 and 1 . In our model, which does not include the late phases of ${ }^{59} \mathrm{Fe}$ circulation in the organism, compartment 4 plays only a secondary role.

In the experiment the changes in spleen activity recorded (Fig. 3) took place analogously to those in the bone marrow. The maximum (3.2\%), however, is reached only $3 \mathrm{~h}$ after tracer administration, and the subsequent fall also takes place earlier than in the marrow. For this reason the same ferrokinetic compartments were assumed in the spleen as in the bone marrow and only the rate constants were altered somewhat according to the experimental data. Fig. 4 gives another (more detailed) modification of the flows between compartments of the erythropoietic tissue, conforming to our experimental data.

3. Erythrocytes. The incorporation of ${ }^{59} \mathrm{Fe}$ into erythrocytes (Fig. 5) reached its maximum $(68 \%)$ around the 7 th day after tracer administration. In view of the fact that the content of non-haeme iron may be considered negligible in mature erythrocytes, it was possible to consider the erythrocyte pool (No. 8) to 
be a homogenous compartment. Apart from the transfer of haeme iron from the erythropoietic organs, the model also takes into account direct transfer of plasma iron to erythrocytes, apparently effected by temporary binding iron to their membranes.

Immediately after reaching the maximum in the curve of ${ }^{59} \mathrm{Fe}$ incorporation circulating tracer begins gradually to fall off. The rate of this fall corresponds to the values we ascertained in the same mouse strain using ${ }^{14} \mathrm{C}$-glycine (Horký

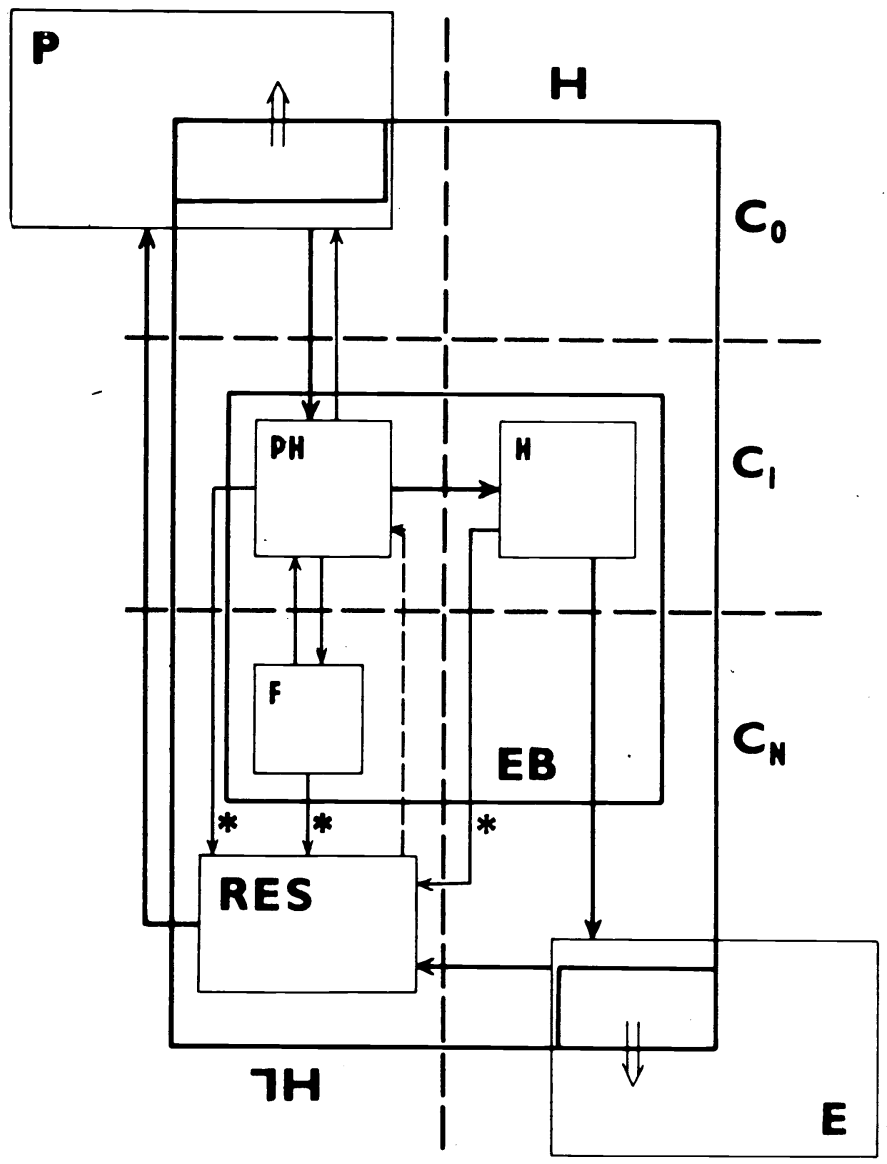

Fig. 4

Scheme of the compartments of the erythropoietic organs of the mouse (bone marrow and spleen). The largest rectangle represents the erythropoietic organs, the right-hand half $(\mathrm{H})$ the haeme fraction, the left-hand half $(\mathrm{H})$ the non-haeme fraction. Both these fractions are divided horizontally to show which components of the time curve of radioactivity of the erythropoietic organs individual compartments of the model were based on. $\mathrm{C}_{0}$ corresponds to the rising component of the curve, $\mathrm{C}_{1}$ to the components of rapid decline, $\mathrm{C}_{\mathrm{N}}$ to the components of slow decline. The square in the upper left-hand corner indicates the plasma compartment $(P)$, that in the bottom right-hand corner the compartment of peripheral erythrocytes (E). The thickly-drawn square in the middle indicates erythroblasts in the haemopoietic organs (EB), which comprise pre-haeme ( $\mathrm{PH}$ ), haeme (H) and storage pool (F). RES - reticuloendothelial system localized in the haemopoietic organs. Arrows show the flows of iron and their thickness corresponds to the latters' intensity; asterisks indicate flows which are not under physiological conditions significant. 


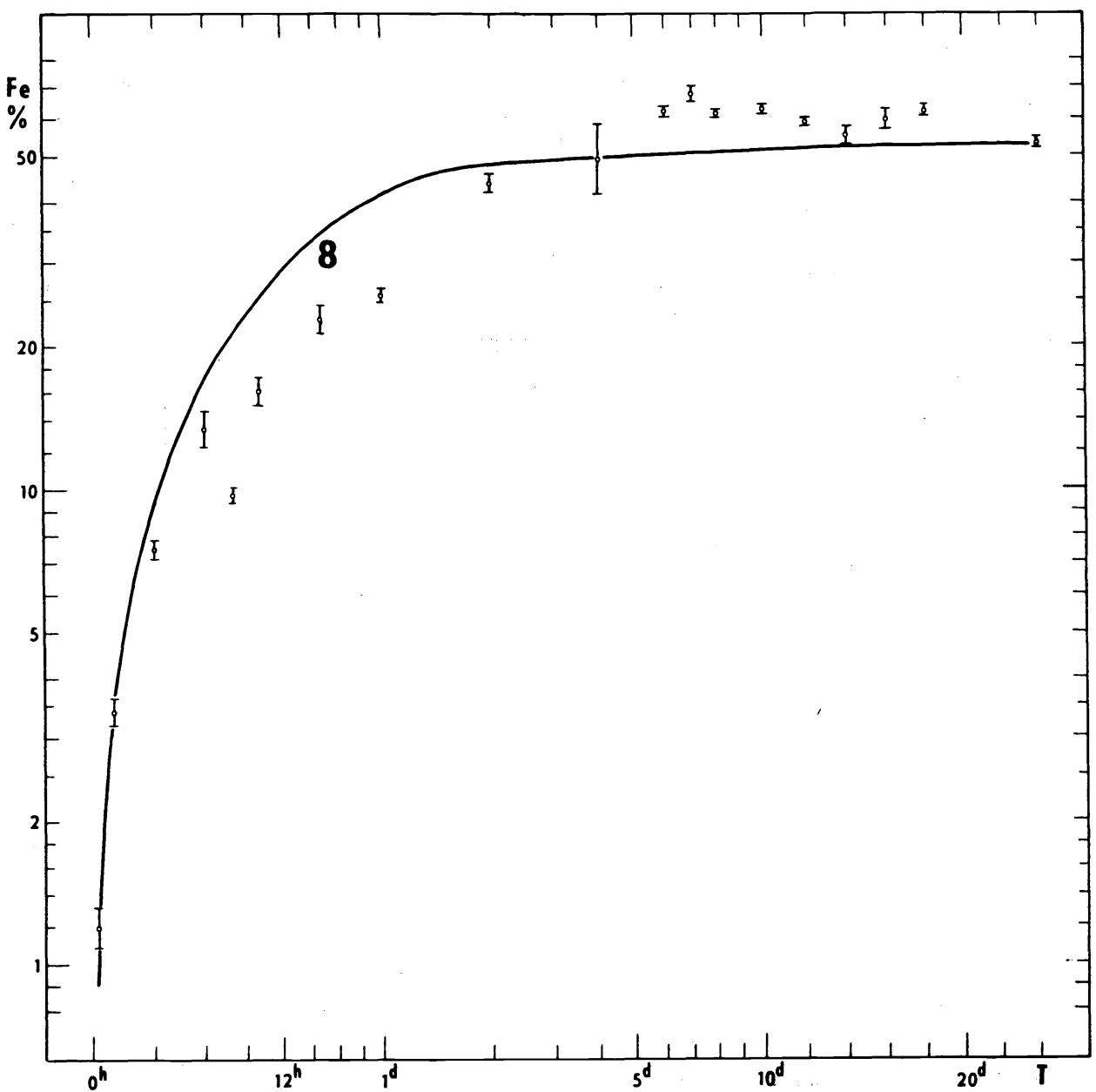

Fig. 5

The radioactivity of all functional erythrocytes of mice following ${ }^{59} \mathrm{Fe}$ administration, plotted against time. Notes as for Fig. 1.

et al. 1978). The rate constants of iron reflux from the erythrocyte compartment into the plasma (through the RES-containing compartments) was chosen in accordance with this experimentally determined rate. The existence of a more rapid component of erythrocyte extinction which appears later was ignored, so that there is a certain disagreement between the theoretical and experimental curves in Fig. 5 towards the end of the experiment.

4. The Liver. The results of measurements of liver radioactivity (Fig. 6) show a sharp increase in radioactivity even in the early stages after ${ }^{59} \mathrm{Fe}$ administration. The maximum is reached around $10 \mathrm{~h}$ (approximately $8.5 \%$ administered radioactivity), followed by a plateau up to about $48 \mathrm{~h}$ after administration. Only then does the radioactivity begin to fall gradually. Curves 1 and 8 at the bottom of the figure correspond to the contribution of unperfused blood to the sum 
curve of liver radioactivity (thick curve). After their subtraction we obtain curve 9, corresponding to incorporation into the liver tissue proper.

Practically all the storage iron pool contained in the liver of rats is localized in the hepatocytes (Cook et al. 1974). Hershko et al. (1973) found by quantitative autoradiography that $97-100 \%$ of ${ }^{59} \mathrm{Fe}$ incorporated from transferrin by rats' livers is localized in hepatocytes. In view of these observations and of the fact that in the interval we observed there was no great decrease in the number of erythrocytes in the peripheral blood, which might have increased the quantity of ${ }^{59} \mathrm{Fe}$ in the liver RES, the whole of compartment 9 could be identified with the hepatocytes and considered internally homogenous. The model assumes a mutual exchange of tracer only between compartment 9 and the plasma.

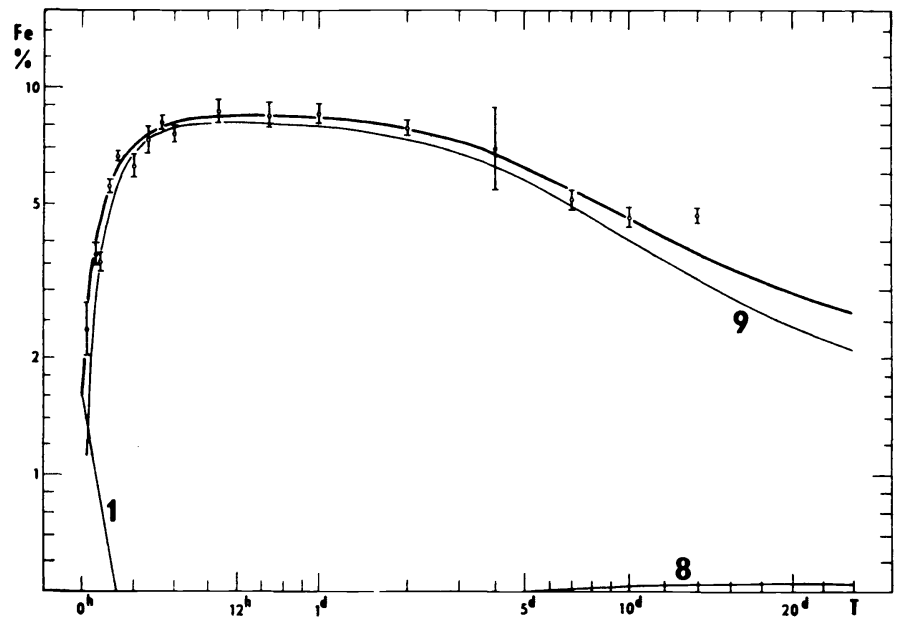

Fig. 6

Radioactivity in the liver (after perfusion with saline) following the administration of ${ }^{59} \mathrm{Fe}$ to mice, plotted against time. Curves 1 , 8 and 9 correspond to the calculated radioactivities of the compartments with the same numbers, the thicker curve without marking being their sum and representing an approximation of the total radioactivity of the liver. Other notes as in Fig. 1.

5. Losses. Fig. 8 shows the loss of activity of the whole organism as ascertained by measuring the activity of faeces and urine. The initially exponential course of the curve flattened out around the 5th day after fracer administration. There is a certain non-correspondence of the theoretical and experimental values, apparently due to tracer delay, which the model does not take into account; a more accurate picture could be obtained by increasing the number of compartments in the organs not studied. However, such an increase in precision would not have any great effect on the other flows, which is why it was not sought, in view of the fact that the number of unknowns in the system would be increased by an unacceptable amount.

6. Organs and Tissues not Studied. The course of radioactivity calculated for this iron pool is shown in Fig. 7 by the thick curve. The figure shows that between the 8th and 12th hours following tracer administration up to $38 \%$ of all administered iron is contained in this pool. After the 12th hour, however, 


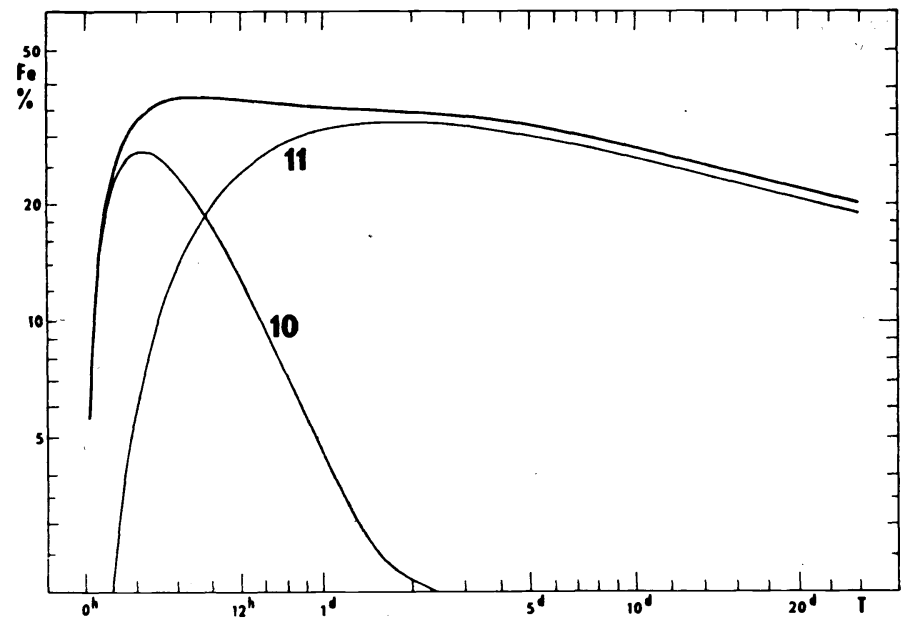

Fig. 7

Curves derived by calculation, simulating the course in time of the radioactivity of the organs not studied following i. v. administration of ${ }^{59} \mathrm{Fe}$ to mice. The thicker, unmarked curve, corresponding to the sum of these organs, was divided into two components, corresponding to the model compartments 10 and 11 . Other notes as Fig. 1.

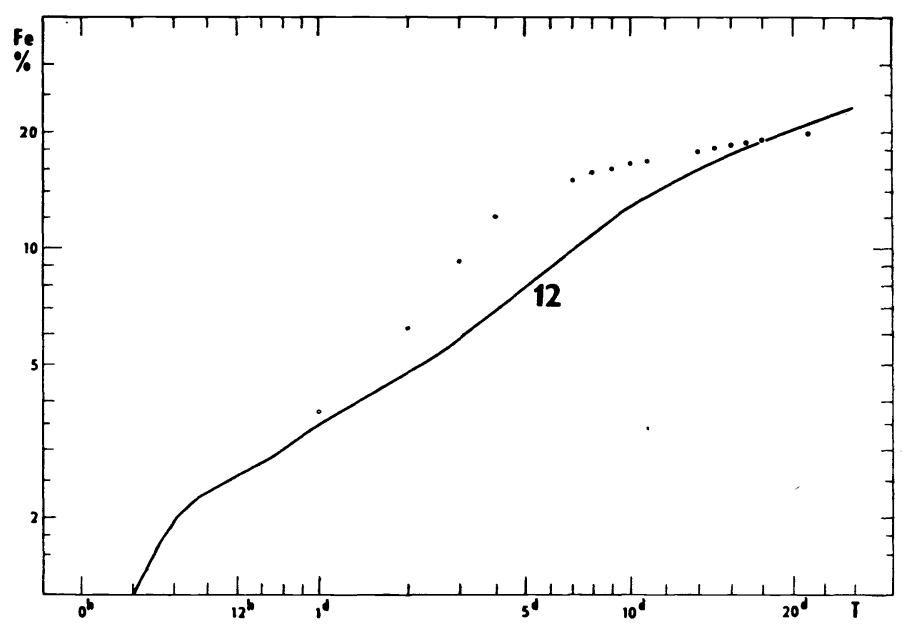

Fig. 8

Losses of ${ }^{50} \mathrm{Fe}$ from the crganism following i.v. administration to mice, plotted against time. The circles indicate experimentally ascertained values, the curve is the result of the model calculation.

Other notes as Fig. 1.

there is a fall which corresponds to an outflow of $17 \%$ initially administered activity from this pool over the next three weeks. However, in the course of these three weeks ${ }^{59} \mathrm{Fe}$ continues to be incorporated by the organs not under observation (tracer in the plasma is available all the time), so that the total flow through 
these organs is substantially greater than $20 \%$, which is the size of losses of ${ }^{59} \mathrm{Fe}$ from the organism over these first three weeks (see Fig. 8). This necessarily implies that a portion of the ${ }^{59} \mathrm{Fe}$ applied returns from these organs into those under observation. The sum curve in Fig. 7 can reasonably be decomposed mathematically into 2 or 3 components; however, model calculations showed that division into three components does not bring any great improvement in the approximation of experimental data, so the sum curve was taken as the product of the superimposition of two components only (compartments 10 and 11). The two curves differ strongly in the timing of their maxima and in overall shape. The maximum of compartment 10 is around $5 \mathrm{~h}$ ( $28 \%$ of administered activity) and there followed a sharp decline, flattening out around the 60th hour after tracer administration. The maximum radioactivity of compartment 11 is not until the end of the second day ( $33 \%$ applied radioactivity) and the subsequent decline is much milder than that of compartment 10.

The relation between the curve of plasma clearance and the curves of ${ }^{59} \mathrm{Fe}$ incorporation into the two erythropoietic organs and the liver indicate that the level of tracer in the plasma falls much faster than is to be expected from a mere transfer into these organs. The only possible receptor of this iron from the plasma compartment is compartment 10 , into which iron apparently flows at a rapid rate, moving on into the organs not studied, with part of it returning with a certain lag to the plasma and part leaving the body. The existence of compartment 10 and the source of radioactivity in it shown in Fig. 7 are the only possible explanation of the apparent discrepancy between the clearance curve of plasma iron and the incorporation curve of tracer into the erythropoietic organs.

If equilibrium is reached between compartment 10 and the plasma relatively quickly, then from the physiological point of view the explanation that compartment 10 represents the extravascular space is very probably (interstitial fluid and lymph in lymphatics). Such an explanation of compartment 10 would be borne out by the ease with which transferrin penetrates the capillary wall into the interstitial fluid and the relatively high proportion of extravascular transferrin, exceeding that of plasma transferrin (Morgan 1966). The existence of a significant extravascular compartment in equilibrium with the plasma was emphasized by Cavill and Ricketts (1980). On the basis of the data of. Cheney et al. (1967) it may be supposed that a similar compartment also exists in rats, though to a much smaller extent.

Compartment 11 represents the iron which is relatively firmly fixed in the organs not studied (skin, muscles, urogenital tract, intestine, etc.). In the model it mainly exchanges its iron with compartment 10 (the extravascular space of these organs). Compartments 10 and 11 in the model are also pathways for the excretion of iron from the organism.

7. The Overall Scheme of the Ferrokinetics of Mice. The results of experiments in which the total amount of iron and the amount of haeme iron in the tissues and organs of the mouse were ascertained are summarized in Tab. I. The masses are per organ without adjustment for body mass and are expressed in $\mathrm{nmol} \mathrm{Fe}$ (except for body mass). The values in brackets indicate $\%$ of total body iron content. The plasma turnover was $27.59 \pm 3.60 \mu \mathrm{mol} \mathrm{Fe} / 100 \mathrm{~cm}^{3}$ whole blood per day.

The total scheme of the fluxes of iron in mice given by our model is shown in Figs. 9 and 10. In Fig. 9 the unbroken rectangles represent individual compartments of the model, the dashed ones the physiological complexes of compart- 
ments: A - bone marrow, B - spleen, C - blood, D - organs not studied. The numbers beside the arrows give the rate constants $\lambda$ of individual intercompartmental flows in $\%$ of the size of the compartment from which the flow

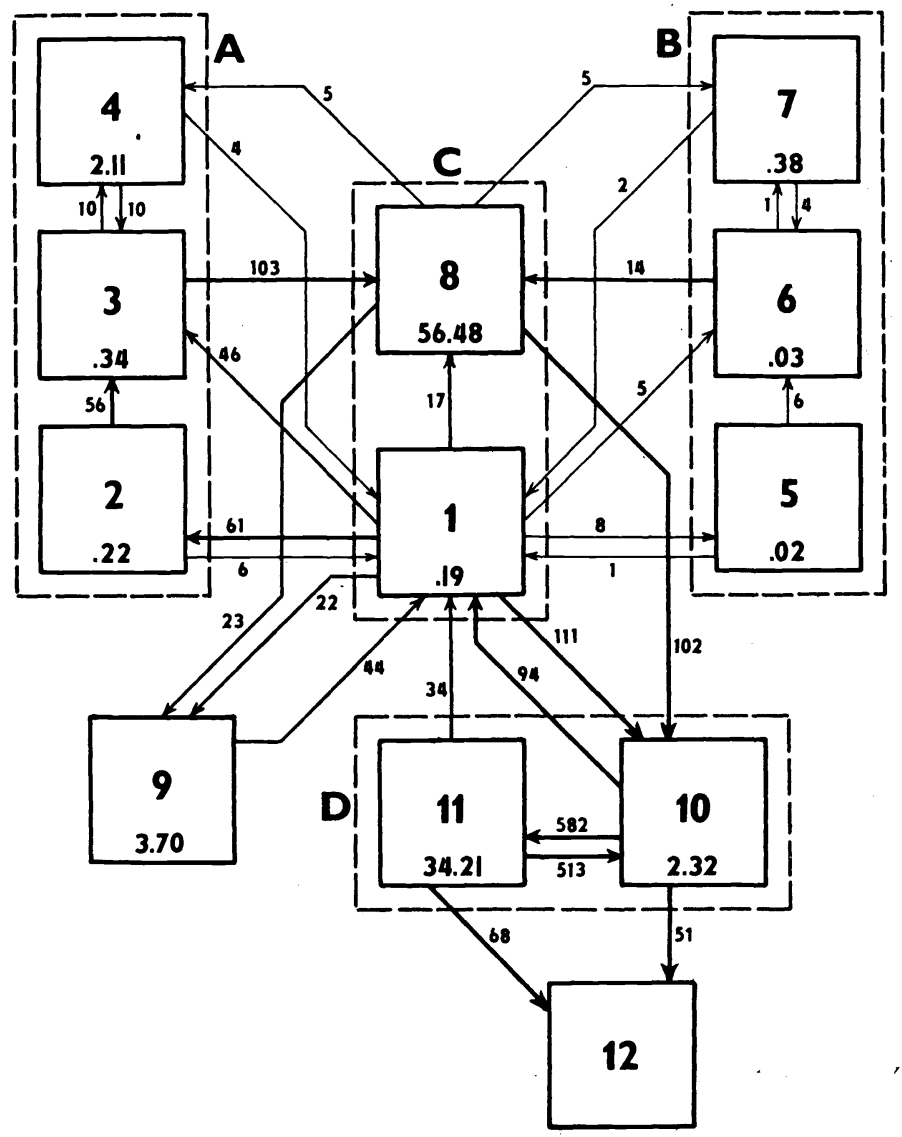

Fig. 9

Scheme of the internal exchange of iron in mice of the strain $\mathrm{C} 57 \mathrm{BL} / 10 \mathrm{ScSnPh}$, relative values. The full squares represent the compartments of the model, the dashed rectangles the physiological complexes which are formed by them: 1 - plasma, 2, 3, 4 compartments of the bone marrow, 5, 6, 7 - compartments of the spleen, 8 - functional (circulating) erythrocytes, 9 - liver, 10, 11 - compartments not studied, 12 - losses; A - bone marrow, B - spleen, C - blood, D - organs not studied. Arrows indicate flows of iron, the numbers beside them giving the rate constants $l_{i j}$ of individual flows between compartments (in percentages of the size of compartment from which flow originates, flow in that direction per day).

takes place, flowing in the given direction per day. One hundred times the reciprocal values of these numbers gives the time in which the compartment from which the flow originates decreases to $1 / \mathrm{e}$. In the rectangles for individual compartments in Fig. 10 the $\%$ values $0_{\text {; relat }}$ contributed by individual compart- 


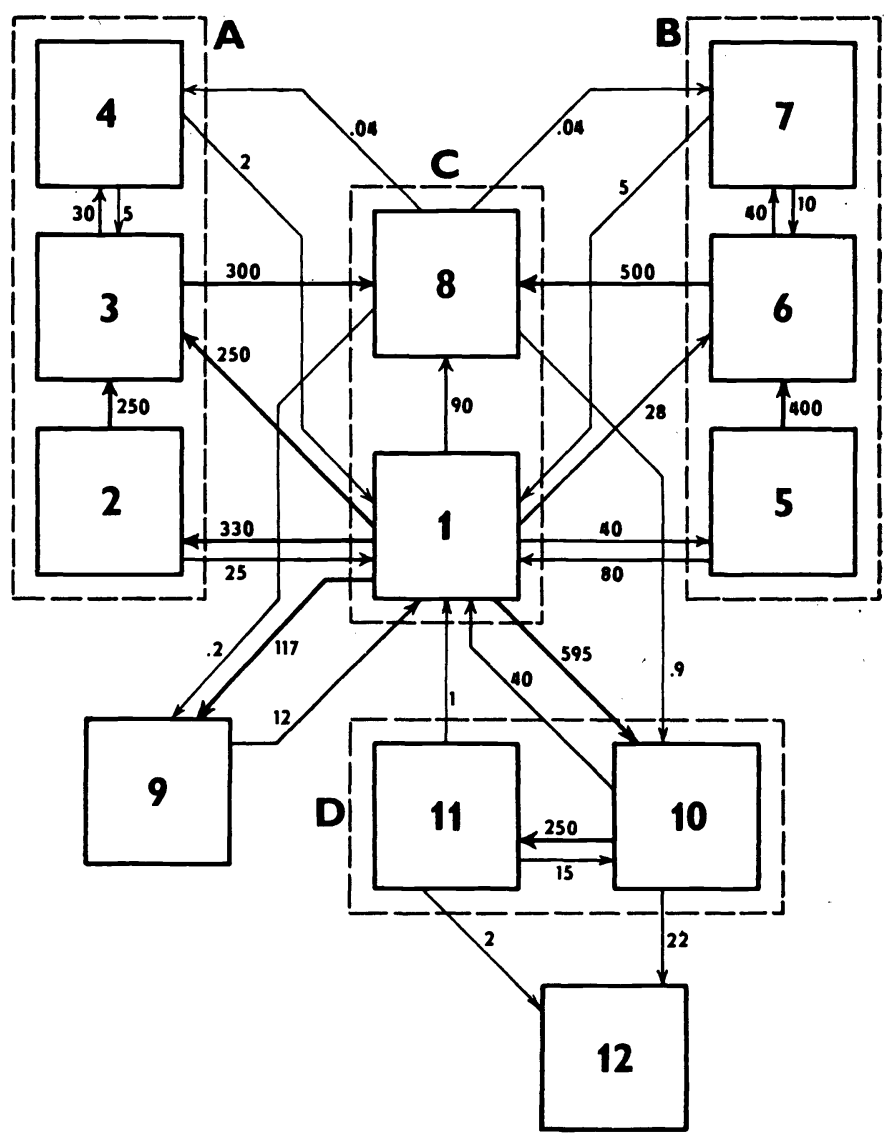

Fig. 10

Scheme of the internal exchange of iron in mice of the strain $\mathrm{C} 57 \mathrm{BL} / 10 \mathrm{ScSnPh}$, absolute values. Compartments or groups of compartments are designated as in Fig. 9. The flows shown by arrows are expressed here as absolute values in hundredths of a per cent of the total content of iron in the organism. The numbers in the lower part of the squares indicate the amount of iron in individual compartments as \% of the total iron content of the organism. These values were derived by calculation from the model after the tracer had reached a state of equilibrium; they are comparable to the values obtained by chemical analysis of the organs and tissues, Tab. I.

ments to the distribution of elementary iron in the whole organism are given. These values were calculated from the model, and correspond to a state where the tracer has dispersed evenly throughout the whole body (the 140th day after tracer administration). The flows of iron $k_{i j \text { relat }}$ indicated by the arrows are expressed in this figure in hundredths of a per cent of the total iron content of the organism.

The validity of the model independent of all other methods can be verified by comparing the values of $o_{j \text { relat }}$ (Fig. 10) with the corresponding values obtained by chemical analysis (Tab. 1, figures in brackets). The minor differences 
Table 1

Total iron, haeme and non-haeme iron content in mouse organs in nmol and in percent of total iron content in the whole body (in brackets)

\begin{tabular}{|c|c|c|c|}
\hline Organ (tissue) & Total iron & Haeme iron & Non-haeme iron \\
\hline Plasma & & & $\begin{array}{c}48.5 \times 2.20 \\
(0.18 \%)\end{array}$ \\
\hline Erythrocytes & & $\begin{array}{c}15600 \pm 400 \\
(57.1 \%)\end{array}$ & \\
\hline Spleen & $\begin{array}{c}343.8 \pm 34.0 \\
(1.26 \%)\end{array}$ & $\begin{array}{c}125.5 \pm 7.2 \\
(0.46 \%)\end{array}$ & $\begin{array}{c}218.5 \pm 34.0 \\
(0.80 \%)\end{array}$ \\
\hline Femur & $\begin{array}{r}105.5 \pm 7.0 \\
(0.39 \%)\end{array}$ & $\begin{array}{c}38.9 \pm \\
(0.14 \%)\end{array}$ & $\begin{array}{c}67.5 \pm 7.2 \\
(0.25 \%)\end{array}$ \\
\hline Whole skeleton & $\begin{array}{c}2161 \pm 118 \\
(7.91 \%)\end{array}$ & $\begin{array}{r}1146 \pm 50 \\
(4.20 \%)\end{array}$ & $\begin{array}{c}1015 \pm 129 \\
(3.72 \%)\end{array}$ \\
\hline Liver & & & $\begin{array}{c}2185+395 \\
(8.00 \%)\end{array}$ \\
\hline Whole mouse & $\begin{array}{c}27310 \pm 890 \\
(100.00 \%)\end{array}$ & & \\
\hline Body mass & $26.3 \pm 0.4 \mathrm{~g}$ & & \\
\hline
\end{tabular}

between the model calculation and the results of chemical analysis in compartments 1 and 8 are within the scope of error of measurement. The bone marrow as a whole (A) contains less iron in the model than would correspond to the results of chemical analysis, which is mainly due to the disparity in compartment 3 (haeme iron of erythron). The difference is caused by the presence of a relatively large amount of peripheral blood in the bone marrow, as was shown by corresponding measurements made using ${ }^{51} \mathrm{Cr}$-labelled erythrocytes (Vácha et al. 1980), see also scheme in Fig. 4. According to these measurements peripheral erythrocytes present in the bone marrow contain $3.1 \%$ of the total $\mathrm{Fe}$ in the organism, which when added to the model value of 2.67 gives reasonably good agreement with the results of chemical analysis of the marrow. There is an analogous situation in the spleen, where the peripheral erythrocytes contain $0.58 \%$ of the total iron in the organism. When this is added to the model value of 0.43 we get an acceptable degree of agreement with the results of chemical analysis. The remaining differences between the model calculation and the directly ascertained iron content in these two organs result from a certain additional non-homogeneity of the real compartments, which it has not yet been possible to take into account in the model. The picture produced by the model, corresponding to the tracer kinetics, accurately reflects rapid processes, while the chemical analysis of organs reflects a state of equilibrium. In the case of the existence of subcompartments with a slower exchange of iron the overall size of compartments in the model must necessarily be underestimated compared with the results of chemical analysis.

There was a more pronounced disparity in compartment 9 (liver), but this is 
apparent even between the primary experimental data obtained on the one hand using tracer and on the other hand by chemical analysis. The results of chemical analysis of the liver were subject to a considerable dispersion in repeated experiments, not explicable as methodical error. Even in a physiologically normal state the iron content in the liver probably fluctuates considerably according to the availability of iron in food, etc.

In some cases the compartments of ferrokinetics are apparently the sum of several components (especially compartments 4, 7, 10 and 11). Apart from this the possibility of some less significant (small) flows of iron having been left out of the model or taking place somewhat differently cannot be excluded. The following basic features of the ferrokinetics of the mouse strain used can, however, be considered to have been demonstrated by our analysis:

1. The central pool of ferrokinetics in the mouse consists not only of the plasma but also of a further space with which the plasma exchanges iron mutually. This pool can in all probability be identified with the extravascular and lymphatic space.

2. The ferrokinetics of the mouse are, due to the existence of the extraplasmatic iron pool with a rapid turnover, very complicated. There are large transfers of iron from the plasma pool to compartments which are not accessible to direct observation. It is clear that in mice at least the course of the plasma clearance of ${ }^{59} \mathrm{Fe}$ and the value of PIT derived from it are far from being an accurate indication of the intensity of erythropoiesis.

3. The primary incorporation of labelled iron into the erythropoietic organs of mice is directed not only into the haeme pool in the erythroblasts but also into non-haeme compartments. The non-haeme compartment with a rapid turnover of iron has for the most part a pre-haeme character, in addition returning part of its iron to the plasma. The compartment with a slower turnover is approximately ten times larger (Fig. 10) and has the nature of a storage iron pool. Both non-haeme pools are at least partly localized outside the erythroblasts, while the second of them has as a whole no direct relation to erythropoiesis. The proportion of individual components in the overall incorporation of ${ }^{59} \mathrm{Fe}$ into the erythropoietic organs changes greatly with the length of incorporation, and in view of their different physiological significance, undoubtedly also under conditions where haemopoiesis is out of equilibrium. Thus the incorporation of labelled iron into the erythropoietic organs as a whole is not suitable for monitoring the intensity of erythropoiesis, for which purpose the haeme fraction only must be considered. We have worked out and published elsewhere a suitable method of doing this in small laboratory animals (Vácha et al. 1978).

\section{Vnitřní kinetika železa u myši}

U myší kmene C57BL/10ScSnPh byla sledována v průběhu tř́i týdnů po aplikaci ${ }^{59} \mathrm{Fe}$ radioaktivita plasmy, erytrocytů, jater, hemového a nehemového železa kostní dřeně a sleziny, moče a stolice. Na základě získaných experimentálních dat byly pomocí matematického modelování zjištěny rychlosti tokư mezi předpokládanými kompartmenty železa $\mathrm{v}$ organismu. Pomocí chemického stanovení obsahu hemového a nehemového železa $\mathrm{v}$ těchto orgánech bylo možno tyto toky vyjádřit $\mathrm{v}$ absolutních hodnotách a vytvořit tak souhrnnou modelovou prèsstavu ferrokinetiky u myši.

Z modelu jednoznačně vyplývá, že centrálním ferrokinetickým fondem (,poo- 
lem“c) u myši je nejen plasma, ale $i$ další prostor o značném objemu a rychlosti výměny, který lze s velkou pravděpodobností ztotožnit s extravaskulárním a lymfatickým prostorem. Také $\mathrm{v}$ erytropoetických orgánech byly zjištěny nehemové fondy značné velikosti. Ten $\mathrm{z}$ nich, který se obměňuje rychleji, má $\mathrm{z}$ velké části prehemový charakter, druhý fond, asi o řád větší, $s$ pomalejší obměnou, nemá jako celek bezprostřední vztah $k$ erytropoese a je proto hlavní příčinou diskrepancí mezi výsledky inkorporace ${ }^{59} \mathrm{Fe}$ do erytropoetických orgánů a skutečnou intensitou erytropoesy.

\section{Внутренная кинетика железа у мышей}

У мышей линии C57BL/10ScSnPh исследовалась в течении трех недель после введения ${ }^{59} \mathrm{Fe}$ радиоактивность плазмы, эритроцитов, печени, гемового и негемового железа костного мозга и селезенки, мочи и испражнений. На основании полученных экспериментальных данных при помощи математического моделирования были установлены скорости токов между предполагаемыми компартментами железа в организме. При помощи химического определения содержания гемового и негемового железа в әтих органах было возможно эти токи выразить в абсолютных величинах и таким образом создать общее модельное представление о феррокинетике у мышей.

На основании модели однозначно вытекает, что центральным феррокинетическим пулом у мышей является не только плазма, но и дальнейшее пространство со значительным объемом и скоростью обмена, которое можем с большой достоверностью отождествить с экстраваскулярным и лимфатическим пространством. Так же в эритропоэтических органах были обнаружены негемовые пулы значительного размера. Тот из них, который обменивается быстрее, имеет с большей части негемовый характер, второй пул, на порядок больчий, с более медленным обменом, не имеет в целом непосредственное отношение к эритропоэзу и поэтому является главной причиной несоответствия между результатами инкорпорирования ${ }^{59} \mathrm{Fe}$ в эритропоэтические органы и действительной интенсивностью эритропозза.

\section{References}

BOTHWELL, T. H. - HURTADO, A. V. - DONOHUE, D. M. - FINCH, C. A.: Erythrokinetics. IV. The plasma iron turnover as a measure of erythropoiesis. Blood, 12, 1957: $409-427$.

BRODSKY, I. - DENNIS, L. H. - KAHN, S. B. - BRADY, L. W.: Normal mouse erythropoiesis. I. The role of the spleen in mouse erythropoiesis. Canc. Res., 26, 1966: 198-201.

CAVILL, I. - RICKETTS, C.: The kinetics of iron metabolism. In: Iron in Biochemistry and Medicine, Ed.: A. Jacobs and M. Worwood, Academic Press, London, 1974: 613-647.

CAVILL, I. - RICKETTS, C.: Human iron kinetics. In: Iron in Biochemistry and Medicine, II, Ed.: A. Jacobs and M. Worwood, Academic Press, London, 1980: 573-604.

CHENEY, B. A. - LOTHE, K. - MORGAN, E. H. - SOOD, S. K. - FINCH, C. A. Internal iron exchange in the rat. Am. J. Physiol., 212, 1967: 376 - 380.

COOK, J. D. - HERSHKO, C. - FINCH, C. A.: Storage iron kinetics. IV. Cellular distribution of ferritin iron stores in rat liver. Proc. Soc. Exp. Biol. Med., 145, 1974: 1378-1381.

FINCH, C. A. - DEUBELBEISS, K. - COOK, J. D. - ESBACH, J.W. - HARBER, L. A. FUNK, D. D. - MARSAGLIA, G. - HILLMAN, R. S. - SLICHTER, S., - ADAMSON, J. W. - GANZONI, A. - GIBLETT, E. R.: Ferrokinetics in man. Medicine, 49, 1970: $17-53$.

GRULICH, I.: Osteologische Präparation mit der Verwendung der kadaverikolen Käfer (Dermestes vulpinus Fbr., Coleoptera, Insecta). Lynx (Prague) n. s., 19/1977, 1977: 87-98. 
HERSHKO, C. - COOK, J. D. - FINCH, C. A.: Storage iron kinetics. III. Study of desferrioxamin action by selective radioiron labels of $\mathrm{RE}$ and parenchymal cells. J. Lab. Clin. Med., 81, 1973: 876-886.

HOLÁ, J. - VACHA, J. - ZNOJIL, V. - KLEINWÄCHTER, V.: Studies on non-haemoglobin erythrocyte iron: the influence of haemolysis on plasma iron determinations. Clin. Chim. Acta, 61, 1975: 121-126.

HORKÝ, J. - VÁCHA, J. - ZNOJIL, V.: Comparison of life-spans of erythrocytes in some inbred strains of mouse using ${ }^{14} \mathrm{C}$-labeled glycine. Physiologia Bohemoslov., 27, 1978: 209-217.

JACOBS, A.: Erythropoiesis and iron deficiency anaemia. In: Iron in Biochemistry and Medicine, Ed.: A. Jacobs and M. Worwood, Academic Press, London, 1974: 405-436.

KINDLER, E.: Computer software for modelling of compartmental systems. In: Computers in Radiology, Ed.: R. de Haene and A. Wamberzie, Karger Verlag, Basel, 1970: 444-449:

MONTI, A. - GLYNN, M. F. - DERN, R. J.: Studies with doubly labeled iron. III. An evaluation of ferrokinetic data obtained with various chemical forms of tracer iron. J. Lab. Clin. Chem., 61, 1963: 272-279.

MORGAN, E. H.: Transferrin and transferrin iron. In: Iron in Biochemistry and Medicine, Ed.: A. Jacobs and M. Worwood, Academic Press, London, 1974: 30-71.

MORGAN, E. H. - HUEHNS, E. R. - FINCH, C. A.: Iron reflux from reticulocytes and bone marrow cells in vitro. Am. J. Physiol., 210, 1966: 579-585.

POLLYCOVE, $M$,: Iron metabolism and kinetics. Seminars in Hematology, 3, 1966: 235-298.

SKINNER, S. M. - CLARK, R. E. - BAKER, N. - SHIPLEY, A.: Complete solution of the three-compartment model in steady state after single injection of radioactive tracer. Am. J. Physiol., 196, 1959: 238-244.

SMITH, L. H. - CLAYTON, M. L.: Distribution of injected ${ }^{59} \mathrm{Fe}$ in mice. Exp. Hematol., No 20, 1970: 82-86.

VÁCHA, J.: Blood volume in inbred strain BALB/C, CBA/J and C57BL/10 mice, determined by means of ${ }^{50} \mathrm{Fe}$-labelled red cells and ${ }^{59} \mathrm{Fe}$ bound to transferrin. Physiol. Bohemoslov., 24, 1975: 413-419.

VÁCHA, J.: Postirradiational Oscillations of Erythropoiesis in Mice. Academia, Praha, 1982.

VÁCHA, J. - DUNGEL, J. - KLEINWÄCHTER, V.: Determination of the heme and non-heme iron content of mouse erythropoietic organs. Exper. Hematol., 6, 1978: 718-724.

VACHA, J. - HOLÁ, J. - DUNGEL, J. - ZNOJIL, V.: The volume of plasma and erythrocytes in individual bones and in the spleen of mice under physiological conditions and with acute radiation-induced atrophy of the haemopoietic tissue. Acta Haematol., 64, 1980: 165-171. 